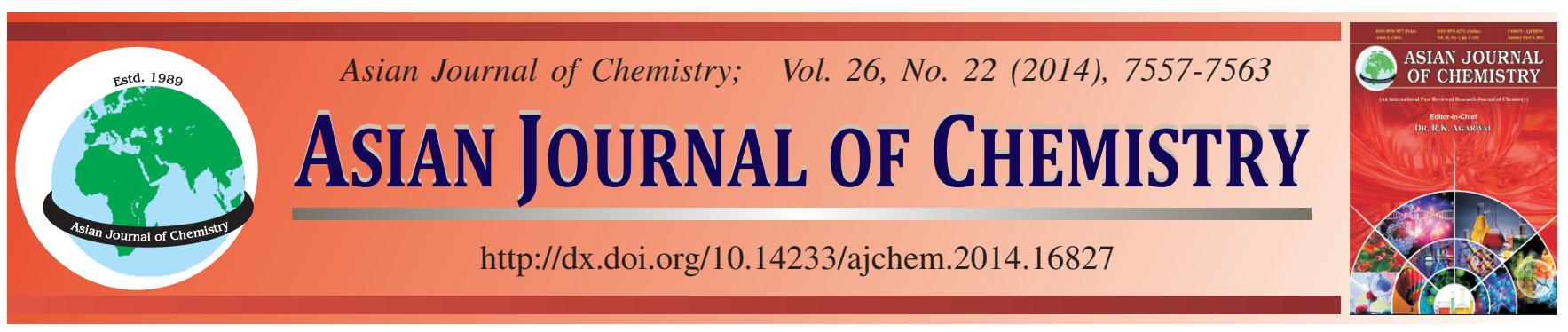

\title{
Anodic Stripping Voltammetric Determination of Trace Cadmium Using Carbon Paste Electrode Modified by 1-Butyl-3-methylimidazolium Tetraflouroborate Ionic Liquid
}

\author{
L.Q. Hung ${ }^{*}$, N.H. Anh, V.T.T. HA and P.H. PhONG
}

Institute of Chemistry, Vietnam Academy of Science and Technology, 18 Hoang Quoc Viet, Cau Giay, Hanoi, Vietnam

*Corresponding author: Fax: +84 43 8361283; Tel: +84 43 8362008; E-mail: hunglq@ ich.vast.ac.vn

\begin{abstract}
Carbon paste electrodes modified with ionic liquid and carbon nanotubes were used for the determination of trace cadmium by anodic stripping voltammetry. The electroanalytical performance for the determination of $\mathrm{Cd}^{2+}$ on the ionic liquid-carbon paste electrode and ionic liquid-carbon nanotube carbon paste electrode (IL-CPE and IL-CNT-CPE) were better than that on the pure carbon paste electrode. Compared with two others, the best electrode obtained in this study was IL-CNT-CPE. The measuring conditions were also optimized. The measurement of trace cadmium on the IL-CNT-CPE had the best response under the conditions of $0.10 \mathrm{M}$ phosphate buffer solution (PBS) (pH 4), deposition potential of $-1 \mathrm{~V}$ and a deposition time of $240 \mathrm{~s}$. The IL-CPE and IL-CNT-CPE revealed highly linear behaviour in the concentration range of 20-100 ppb and 5-220 ppb with detection limits of $5 \mathrm{ppb}$ and $1.48 \mathrm{ppb}$ respectively. The developed sensor has been applied to the determination of $\mathrm{Cd}^{2+}$ in real water samples with satisfactory results.
\end{abstract}

Keywords: Modified carbon paste electrode, Ionic liquid, Cadmium ion, Anodic stripping voltammetry.

\section{INTRODUCTION}

Cadmium is widely used in many industrial processes such as electroplating, painting and battery manufacturing, has been recognized to be a highly toxic and dangerous in the environment. This metal and its compounds are extremely toxic even at low concentrations. The determination of low levels of cadmium is important. because of its ability to bio-accumulate in living organisms as well as in the environment.

Currently, the determination of $\mathrm{Cd}$ in water is typically measured by standard methods such as graphite furnace atomic absorption (GF-AA) 1, inductively coupled plasma mass spectrometry (ICP-MS) ${ }^{2}$, atomic absorption spectroscopy (AAS) ${ }^{3}$, voltametric $^{1-4}$. Compared with the others, voltametric method has several advantages e.g., low-cost inexpensive, easy to use, direct measurement, fast response and portability. Cadmium like most heavy metals is electroactive and it can be electrochemically detected. Therefore, the voltametric method is useful to determine cadmium in the environment. In this method, the conventional working electrode was used to determine the concentration of $\mathrm{Cd}$ in aqueous solution using a glassy carbon, gold, carbon paste electrode (CPE). To improve the electrochemical signal, the electrode modification was investigated and heavily developed in recent years in many ways such as using self-assemble ${ }^{5-9}$, porous ${ }^{10-13}$, film electrode ${ }^{14-20}$. In addition, the change in composition of carbon paste electrode by ionic liquid (IL) has received considerable attention by many scientists because of its useful properties e.g., high chemical and thermal stability, viscosity, negligible vapor pressure and good conductivity ${ }^{21-24}$.

Since the construction of the first carbon paste electrode by Adams in 1958, numerous reports on the fabrication and modification of the carbon paste electrode have appeared to achieve selective, sensitive and reproducible electrochemical biosensors. A carbon paste electrode consists of electrically conducting graphite powder and a non-conductive organic liquid, Nujol and paraffin being the most commonly used. However, carbon paste electrodes display defects associated with poor fabrication reproducibility and mechanical fragility compared to metal electrodes. Therefore, the replacement of the traditionally used Nujol and paraffin with ionic liquids, which serves as a binder and conductor, has been shown to be an attractive and efficient alternative to fabricate electro-chemical sensors. The application of ionic liquids as a binder agent produce more uniform electrodes than those obtained in traditional carbon paste electrodes ${ }^{25}$.

Comparatively, few papers per year on ionic liquidmodified electrodes were published. However, starting after 2005, the usefulness of ionic liquid for electrode modification was recognized and resulted in rapid increase in the number of reports reaching almost 300 in the middle of $2012^{26}$. 
Because of their superior characteristics, ionic liquids have been employed as a binder for carbon paste electrode. The improvement of voltammetric signal when paraffin oil is replaced by ionic liquid was also reported ${ }^{3}$, perhaps due to better properties of the polar components in the binder.

The application of ionic liquids as electrolytes has increased enormously and many review articles can be found in literature $^{27}$. Some articles briefly mentioned electrodes modified with ionic liquid or having ionic liquid as one of the components. There are many ways to modify electrodes using ionic liquids. To date, imidazolium-based ionic liquids with tetrafluoroborate anion have been the focus of numerous publications dealing with their physico-chemical properties, phase equilibria and direct application studies ${ }^{28}$. In a few publications, imidazolium-based ionic liquids were used as a binder for carbon paste electrode ${ }^{29}$.

In this paper, we studied the use of ionic liquid for the modification of carbon paste electrodes. We focused on examining the relationship between the ratios of ionic liquid in the carbon paste electrode with the electrochemical signal of oxidation of cadmium to obtain optimized composition of ionic liquid modified carbon paste electrode (IL-CPE) for the determination of $\mathrm{Cd}^{2+}$ in water. The elctrochemical behaviour of IL-CPE and IL-CNT-CPE was investigated and some parameters were examined to select the best conditions for the determination of cadmium.

\section{EXPERIMENTAL}

All reagents were of analytical grade and were used without additional purification. 1-Butyl-3-methylimidazolium tetraflouroborate $[\mathrm{Bmim}]\left[\mathrm{BF}_{4}\right]$ was received from the Kakuichi laboratory as a gift with a structure as shown in Fig. 1 (Molecular formula: $\mathrm{C}_{8} \mathrm{H}_{15} \mathrm{BF}_{4} \mathrm{~N}_{2}$, formular weight: $226.02 \mathrm{~g}$, m.p. $-71{ }^{\circ} \mathrm{C}, \mathrm{d}=1.21 \mathrm{~g} / \mathrm{mL}$ at $20{ }^{\circ} \mathrm{C}$ )

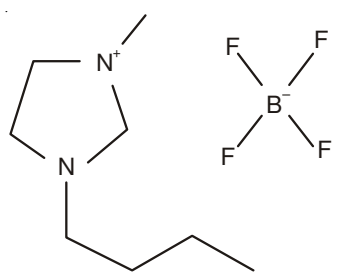

Fig. 1. Molecular structure of ionic liquid used for modification of electrode

Graphite powder obtained from Cica Reagent, Japan and paraffin oil from Wako, Japan were used directly without modification.

Solutions were prepared by dissolving the reagents in distilled water. Stock cadmium and mercury solutions (1000 ppm) purchased from Merck were prepared in $0.1 \mathrm{M}$ nitric acid. The supporting electrolyte for voltammetric experiments was phosphate buffer prepared from dissolving a mixture of $\mathrm{K}_{2} \mathrm{HPO}_{4}$ and $\mathrm{KH}_{2} \mathrm{PO}_{4}$ in distilled water with the $\mathrm{pH}$ adjusted by the addition of $\mathrm{H}_{3} \mathrm{PO}_{4}$ solution. Additional diluted solutions with desirable concentrations were prepared daily from the stock solution.

Voltametric measurements were performed with a homemade potentiostat/galvanostat model PGS-HH5 (Institute of
Chemistry, VAST). The electrochemical cell was used with a conventional three electrode system: $\mathrm{An} \mathrm{Ag} / \mathrm{AgCl} / \mathrm{KCl}$ reference electrode and a platinum wire as a counter electrode. All potentials were given with respect to the $\mathrm{Ag} / \mathrm{AgCl}$ electrode. Working electrodes used in this study were a IL-CPE, IL-CNT$\mathrm{CPE}$ and a conventional carbon paste electrode for comparison.

Preparation of electrodes: The ionic liquid-carbon paste electrode was prepared following similar procedures reported in previous papers ${ }^{30-32}$. The IL-CPE was constructed by thoroughly mixing graphite powder, paraffin oil and $[\mathrm{Bmim}]\left[\mathrm{BF}_{4}\right]$ with different ratios of 80/20/0-EL1, (carbon paste electrode), 80/10/10-EL2 and 80/5/15-EL3, respectively (w/w/w) in a agate mortar for $20 \mathrm{~min}$. The mixture was then tightly packed into one end of a teflon tube ( $5 \mathrm{~mm}$ internal diameter) and a gold wire was inserted through the opposite end for electrical contact. The surface of the IL-CPE and carbon paste electrode was manually smoothed by polishing on clean paper and was then rinsed with distilled water before use without any electrochemical pretreatment.

Electrochemical measurements: The electrochemical behaviour of IL-CPE was investigated by cyclic voltammetry $(\mathrm{CV})$ in $0.01 \mathrm{M} \mathrm{K}_{3}\left[\mathrm{Fe}(\mathrm{CN})_{6}\right] / \mathrm{K}_{4}\left[\mathrm{Fe}(\mathrm{CN})_{6}\right]$ in $1 \mathrm{M} \mathrm{KCl}$ solution to examine the behaviours of prepared electrodes. The detection of cadmium ion was carried out by anodic stripping differential pulse voltammograms (ASDPVA) using the following procedure. First, the cadmium was concentrated on the electrode surface by applying a potential at $-1 \mathrm{~V}(v s . \mathrm{Ag} / \mathrm{AgCl})$ for 240 s in the stirring phosphate buffer solution solution with

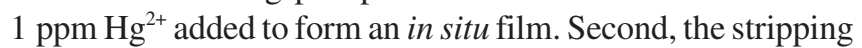
voltammograms were recorded by scanning from $-1 \mathrm{~V}$ to $0.7 \mathrm{~V}$ after $10 \mathrm{~s}$ quiescence. All experiments were carried out at room temperature.

\section{RESULTS AND DISCUSSION}

Electrochemical behaviour of ionic liquid-carbon paste electrode: $\mathrm{K}_{3}\left[\mathrm{Fe}(\mathrm{CN})_{6}\right] / \mathrm{K}_{4}\left[\mathrm{Fe}(\mathrm{CN})_{6}\right]$ was selected as a probe to evaluate the performance of the prepared electrodes. Fig. 2

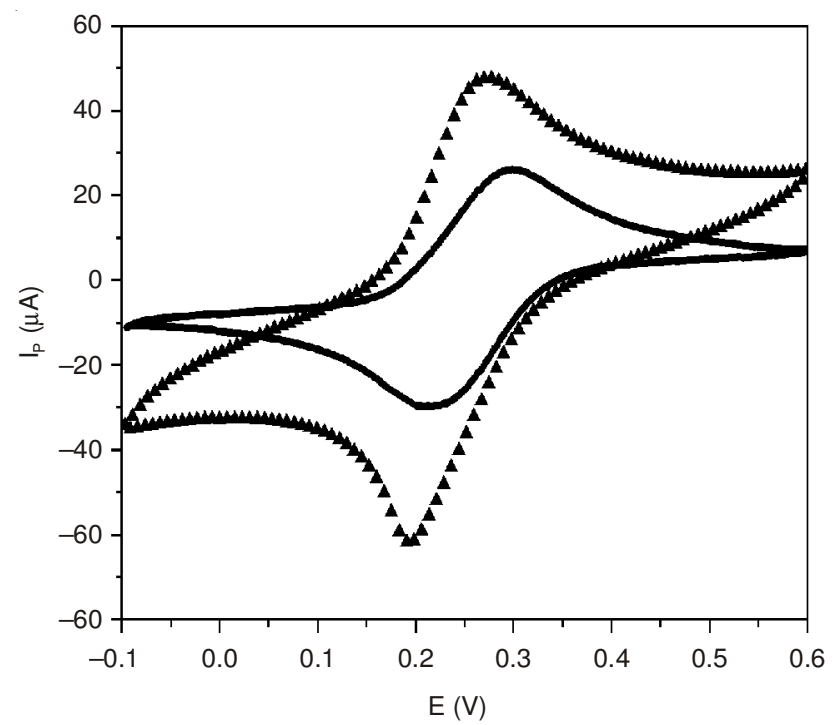

Fig. 2. Cyclic voltammograms of carbon paste electrode and IL-CPE in $0.01 \mathrm{M} \mathrm{K}_{3} \mathrm{Fe}(\mathrm{CN})_{6} / \mathrm{K}_{4} \mathrm{Fe}(\mathrm{CN})_{6}+1 \mathrm{M} \mathrm{KCl}$. Scan rate $10 \mathrm{mV} / \mathrm{s}$, (一) CPE, ( $\Delta$ ) IL-CPE 
shows the electrochemical responses of carbon paste electrode, IL-CPE in $0.01 \mathrm{M} \mathrm{K}_{3}\left[\mathrm{Fe}(\mathrm{CN})_{6}\right] / \mathrm{K}_{4}\left[\mathrm{Fe}(\mathrm{CN})_{6}\right]$ solution. Two clear reversible peaks are visible at a two curve response to $\left[\mathrm{Fe}(\mathrm{CN})_{6}\right]^{3-14-}$ redox couple according to the reaction:

$$
\left[\mathrm{Fe}(\mathrm{CN})_{6}\right]^{3-}+\mathrm{e} \rightarrow\left[\mathrm{Fe}(\mathrm{CN})_{6}\right]^{4-}
$$

It was observed that the peak current of the electrode with the presence of $[\mathrm{Bmim}]\left[\mathrm{BF}_{4}\right]$ ionic liquid $(\boldsymbol{\Delta})$ in the compo-sition significantly increased compared to that at carbon paste electrode $(-)$. The current signal in this case is almost two times higher than that of pure carbon paste electrode.

The results presented indicate that the electrode reaction and the conductivity of carbon paste electrode were greatly improved. This can be explained by the fact that the replacement of paraffin oil with conductive ionic liquid as a binder led to the increase of faradaic signal because of some reactants were transferred through ionic liquid/electrolyte solution and electrode at carbon/ionic liquid interface in IL-CPE body ${ }^{26}$. This does not occur at conventional carbon paste electrodes with nonpolar binder. On the other hand, some carbon graphite particles were covered by paraffin oil behaving as inactive species on the carbon paste electrode surface. The replacement of ionic liquid to paraffin oil made those particles become more active, so the working area surface in IL-CPE was larger than that on carbon paste electrode. The results obtained showed that the presence of ionic liquid not only acted as a binder but also improved the electron transfer ability and surface area in the carbon paste electrode.

Electrochemical signal of cadmium at ionic liquidcarbon paste electrodes: Fig. 3 shows anodic stripping differential pulse voltammograms (ASDPVA) of $\mathrm{Cd}^{2+}(60 \mathrm{ppb})$ in phosphate buffer solution $(0.1 \mathrm{M}, \mathrm{pH} 4)$ at different electrodes. In the blank solution, no current wave was observed. In the presence of $\mathrm{Cd}^{2+}$ in the solution, the well-defined peak appeared at the potential of $-0.67 \mathrm{~V}$ corresponds to oxidation of $\mathrm{Cd}$ to $\mathrm{Cd}^{2+}$.

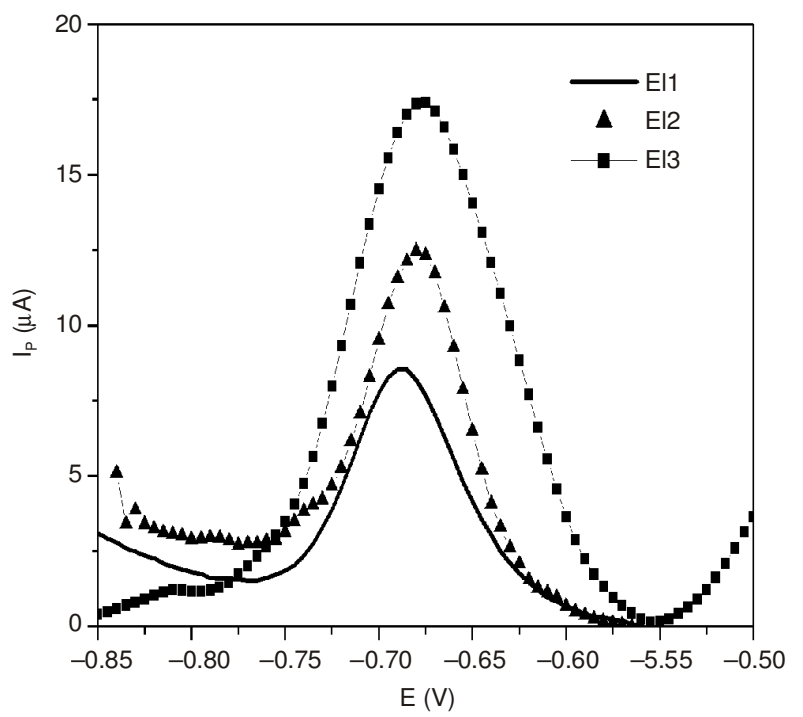

Fig. 3. ASDPVAs of $60 \mathrm{ppb} \mathrm{Cd}^{2+}$ at the IL-CPE with the ratios of graphite powder/paraffin oil/ionic liquid 80/5/15 (ם), 80/10/ 10 ( $\Delta$ ) and 80/20/0 (-), respectively. Curve of blank solution was substracted. Deposition potential: $-1 \mathrm{~V}$, deposition time: $240 \mathrm{~s}$, stripping potential range: $-1 \mathrm{~V}$ to $-0.5 \mathrm{~V}$
It can be seen that the height of the peak was raised with an increase in the amount of ionic liquid in the composition of the modified electrode; e.g., the current at the curve ( $\square$ ) with the ratio of graphite powder/parrafin oil/ionic liquid 80/ $5 / 15$ is $18 \mu \mathrm{A}$, more than two times higher than signals at the curve ( $\Delta$ ) $12 \mu \mathrm{A}$ and about four times higher than that obtained on carbon paste electrode. In the case of increasing the percentage of ionic liquid more than $20 \%$, the electrode surface was visually broken during the accumulation process because of a decrease of paraffin oil that led to a link between graphite particles which in turn became weaker and unstable. This result shows the role of ionic liquid in the composition of carbon paste electrode and that it is possible to improve the possibility of detection of cadmium by using the IL-CPE. The IL-CPE with ratio 80/5/15 was chosen for further experiments.

Effect of $\mathbf{p H}$ : The influence of $\mathrm{pH}$ on the stripping peak current of $\mathrm{Cd}^{2+}$ was investigated in the $\mathrm{pH}$ range of 3-6 in phosphate buffer solution $0.1 \mathrm{M}$ and the results are shown in Fig. 4. It can be seen from Fig. 4 that the acidic environment is more suitable for the stripping process of metal on the ILCPE. This is in agreement with published papers ${ }^{33,34}$. In a study range of $\mathrm{pH}$, the current peak reaches a maximum at $\mathrm{pH} 4$ and decreases with increasing $\mathrm{pH}$ value. At a $\mathrm{pH}<3$, a strong evolution of hydrogen occurred on the electrode surface and dramatically reduced current signal thus affecting the stablility of the electrode. Therefore, the $0.1 \mathrm{M}$ phosphate buffer solution $\mathrm{pH} 4$ was chosen as electrolyte solution for the following experiment.

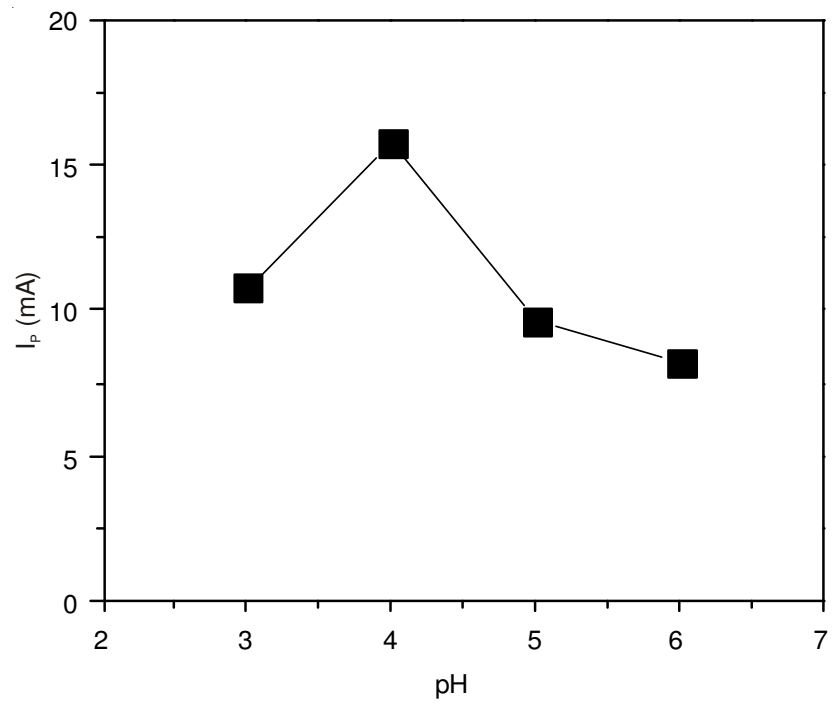

Fig. 4. Effect of $\mathrm{pH}$ on the peak current of $\mathrm{Cd}^{2+}$ at the IL-CPE with ratio $80 / 5 / 15$ in the $0.1 \mathrm{M}$ phosphate buffer solution containing $60 \mathrm{ppb} \mathrm{Cd}^{2+}$

Calibration curves and detection limit: Attempts to build calibration curves and the determination of detection limits were conducted using three different ratios of ionic liquid (EL1, EL2 and EL3).

To verify the practicality of the IL-CPEs for the determination of $\mathrm{Cd}^{2+}$, the stripping processes of the metal ion were investigated. The anodic stripping voltammetric responses of different $\mathrm{Cd}^{2+}$ concentrations in $0.1 \mathrm{M}$ phosphate buffer solution $(\mathrm{pH} 4)$ under the optimized conditions, are shown in Fig. 5. 

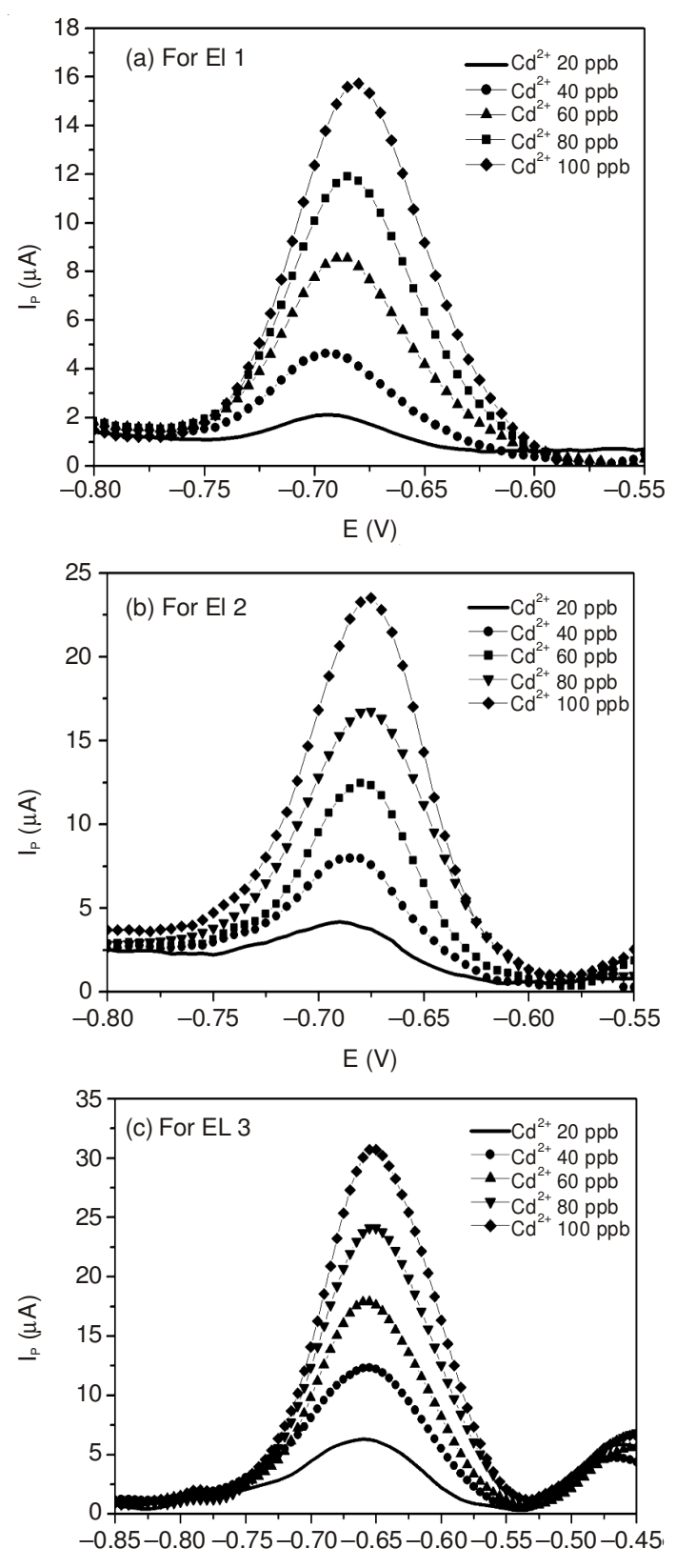

$E(V)$

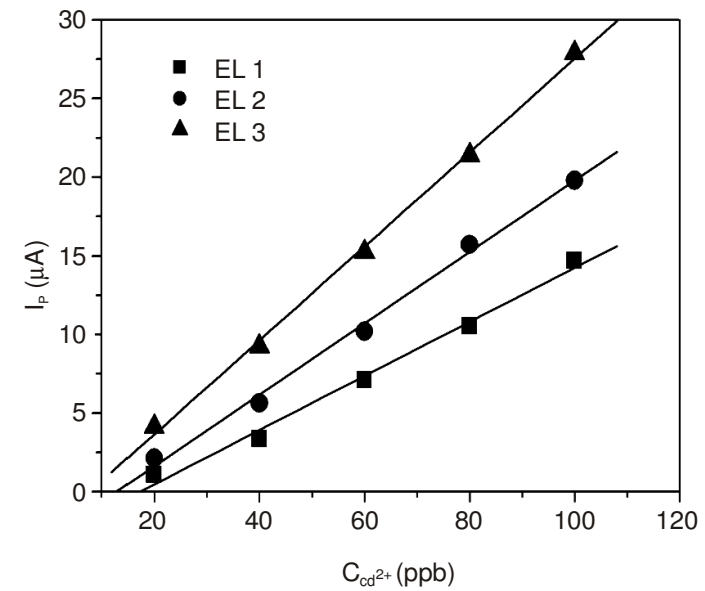

Fig. 5. ASDPVAs of different $\mathrm{Cd}^{2+}$ concentrations in 01.M phosphate buffer solution of $\mathrm{pH} 4$. Concentration of $\mathrm{Cd}^{2+}$ (from 20 to 100 ppb; deposition potential: $-1 \mathrm{~V}$; deposition time: 240s. The inset: calibration curve for determining $\mathrm{Cd}^{2+}$ of the EL1, EL12 and EL3
It can be seen from the inset of Fig. 5 that the peak current has a good linear relationship with the concentration of $\mathrm{Cd}^{2+}$. The linear regression equation for $\mathrm{Cd}^{2+} \mathrm{y}_{1}=0.172 \mathrm{x}-2.959 ; \mathrm{y}_{2}=$ $0.227 \mathrm{x}-2.910 ; \mathrm{y}_{3}=0.298 \mathrm{x}-2.305,(\mathrm{y}: \mu \mathrm{A}, \mathrm{x}: \mathrm{ppb})$ in the concentration range from 20 to $100 \mathrm{ppb}$ and the correlation coefficient is $\mathrm{R}=0.995, \mathrm{R}=09975, \mathrm{R}=0.9990$ for EL1, EL2 and EL3, respectively.

The detection limit, defined as the concentration of the analyte giving signals equivalent to three-time the standard deviation of the blank signals $(\mathrm{S} / \mathrm{N}=3$ ), is $7.83 \mathrm{ppb}$ for EL1, $4.82 \mathrm{ppb}$ for EL2 and $3.72 \mathrm{ppb}$ for EL3, which is as sensitive as that for $\mathrm{Cd}^{2+}$ in the some previous publications ${ }^{35,36}$. The reproducibility of the stripping peak current obtained on ILCPE was investigated by repeated measurements in the solution containing $40 \mathrm{ppb} \mathrm{Cd}^{2+}$. With sample size $\mathrm{n}=5$ the calculated relative standard deviations (RSD) of peak currents were 1.58 $\%$. The high reproducibility indicated that IL-CPE was suitable for analytical measurement.

Adding carbon nanotubes (CNT) into in desired electrodes in order to reduce the detection limit of $\mathrm{Cd}^{2+}$ in the study environment was also studied in order to improve to sensibility of the $\mathrm{Cd}^{2+}$ probe. Since 2003, it has been known that imidazoliumtype ionic liquids tend to form physical gels when grounded with SWCNTs $^{37}$ by physical cross-linking of the nanotube bundles, mediated by local molecular ordering of ionic liquids. Similarly, highly electroconductive material can be formed from polymerizable ionic liquid and SWCNTs ${ }^{37,38}$. IL-CNT gel and analogous material containing carbon microbeads and ionic liquid were first recognized by Professor Shaojun Dong as suitable electrode material ${ }^{39}$. Further studies of these electrodes obtained from variety of hydrophobic or hydrophilic ionic liquids showed the utility of this easily prepared electrode material, which can be deposited in a form of thick film on solid conductive substrate. Although most papers report ILCNT gel electrodes made of SWCNTs, MWCNTs ${ }^{40-44}$ and mesoporous carbon ${ }^{45}$ also form gel films suitable for electrode preparation. These electrodes exhibit larger capacitive current than that of carbon-based material and redox activity characteristic for carbon nanotubes ${ }^{7}$.

The substances used in the preparation of electrodes consist of graphite powder (see above), single wall carbon nanotube, parafin oil and $[\mathrm{Bmim}]\left[\mathrm{BF}_{4}\right]$. Electrolysis modes are exactly as described above $(0.1 \mathrm{M}$ phosphate buffer solution as electrolyte, deposition potential: $-1 \mathrm{~V}$; deposition time: $240 \mathrm{~s}$, potential scan range from -1 to $-0.5 \mathrm{~V} v s$. $\mathrm{Ag} / \mathrm{AgCl}$ ).

Two groups of IL-CPEs were prepared with the ratios indicated in Table-1. The last columm provides the values of peak currents $\left(\mathrm{I}_{\mathrm{p}}\right)$ obtained from each studied electrode with certain content. Concentration of $\mathrm{Cd}^{2+}$ used for those measurements is $60 \mathrm{ppb}$.

Two groups are split in order to verify the content of CNT in the mixture. In group 1, the sum of paraffin oil and ionic liquid was controlled as 20 of the weight while in second group, it was kept as 30 . The ratio of carbon nanotubes varied are shown on Table-1.

From the results in Table-2, we can see clearly that the electrode modified with graphite powder/carbon nanotubes/ paraffin oil/[Bmim] $\left[\mathrm{BF}_{4}\right]$ at 50/20/15/15 in weights, oxidation peak of $\mathrm{Cd}^{2+}$ is highest at $25.553 \mu \mathrm{A}$. The standard curves 


\begin{tabular}{|c|c|c|c|c|c|}
\hline COMP & SITION O & $\begin{array}{r}\text { TA } \\
\text { PREPAREI }\end{array}$ & $\begin{array}{l}\text { LE-1 } \\
\text { IL-CNT-C }\end{array}$ & $\operatorname{AND~I}_{\mathrm{P}} \mathrm{C}$ & AINED \\
\hline Group & $\begin{array}{l}\text { Graphite } \\
\text { powder } \\
(\% \mathrm{w})\end{array}$ & $\begin{array}{c}\text { Abon } \\
\text { nanotubes } \\
(\% \mathrm{w})\end{array}$ & $\begin{array}{c}\text { Paraffin } \\
\text { oil }(\% \text { w) }\end{array}$ & $\begin{array}{c}{[\mathrm{Bmim}]} \\
{\left[\mathrm{BF}_{4}\right]} \\
(\% \mathrm{w})\end{array}$ & $\mathrm{I}_{\mathrm{P}}(\mu \mathrm{A})$ \\
\hline & & & 20 & - & 6.8627 \\
\hline & 75 & 5 & 15 & 5 & 7.5656 \\
\hline & 13 & $J$ & 10 & 10 & 10.282 \\
\hline & & & 5 & 15 & $\mathrm{x}$ \\
\hline & & & 20 & - & 7.8442 \\
\hline & & & 15 & 5 & 7.9769 \\
\hline 1 & 70 & 10 & 10 & 10 & 10.907 \\
\hline & & & 5 & 15 & $\mathrm{x}$ \\
\hline & & & 20 & & 9.1708 \\
\hline & & & 15 & 5 & 9.9210 \\
\hline & 65 & 15 & 10 & 10 & 10.032 \\
\hline & & & 5 & 15 & $\mathrm{x}$ \\
\hline & & & 30 & 0 & 9.1556 \\
\hline & 60 & 10 & 20 & 10 & 13.317 \\
\hline & 60 & 10 & 15 & 15 & 20.355 \\
\hline & & & 10 & 20 & $\mathrm{x}$ \\
\hline & & & 30 & 0 & 9.4010 \\
\hline & & & 20 & 10 & 16.801 \\
\hline II & 50 & 20 & 15 & 15 & 25.553 \\
\hline & & & 10 & 20 & $\mathrm{x}$ \\
\hline & & & 30 & 0 & 8.7261 \\
\hline & 40 & 30 & 20 & 10 & 9.4010 \\
\hline & 40 & 30 & 15 & 15 & $\mathrm{x}$ \\
\hline & & & 10 & 20 & $\mathrm{x}$ \\
\hline
\end{tabular}

were built using this ratio as the best case. Fig. 8 shows the anodic stripping voltammetric responses of different $\mathrm{Cd}^{2+}$ concentrations in $0.1 \mathrm{M}$ phosphate buffer solution ( $\mathrm{pH} 4$ under the optimized conditions (graphite powder/carbon nanotubes/ paraffin oil/[Bmim] $\left[\mathrm{BF}_{4}\right]$ at 50/20/15/15 in weights). It can be seen from the inset of Fig. 6 that the peak current has a good linear relationship with the concentration of $\mathrm{Cd}^{2+}$. The linear regression equation for $\mathrm{Cd}^{2+} \mathrm{y}=0.95301+0.413 \mathrm{x}$, (y: $\mu \mathrm{A}, \mathrm{x}: \mathrm{ppb})$ in the concentration range from 20 to $100 \mathrm{ppb}$ with a correlation coefficient of $\mathrm{R}^{2}=0.99934$. The detection limit is determined as $5 \mathrm{ppb}$. The reproducibility of the stripping peak current obtained on this modified IL-CNT-CPE was investigated by repeated measurements in the solution containing $20 \mathrm{ppb} \mathrm{Cd}^{2+}$ (Fig. 7). With a sample size $\mathrm{n}=10$ the calculated relative standard deviations (RSD) of peak currents were $1.58 \%$.

It can be seen from Table-2 that most of ions had little interference for the signals of $\mathrm{Cd}^{2+}$ at $20 \mathrm{ppb}$, even at a concentration of a thousand times higher. For $\mathrm{Cu}^{2+}$ and $\mathrm{Pb}^{2+}$ ions, in the presence of high concentration of $\mathrm{Cu}^{2+}$ and $\mathrm{Pb}^{2+}$ (100 times higher), the stripping peak current of $\mathrm{Cd}^{2+}$ decreases. Major interferences include intermetallic compound formation, overlapping stripping peaks adsorption of organics and complexation. In this case, when $\mathrm{Cd}^{2+}, \mathrm{Cu}^{2+}$ and $\mathrm{Pb}^{2+}$ are present simultaneously, cadmium forms intermetallic compounds with copper and also competes with $\mathrm{Pb}$ for surface active sites. As a result, the stripping peak for the constituent metals may be severely depressed or shifted and additional peaks due to intermetallic compound stripping may be observed.

An attempt with a mixture of above metallic ions was also done to investigate the interference between them when they are coexisting in solution. Concentration of all above ions

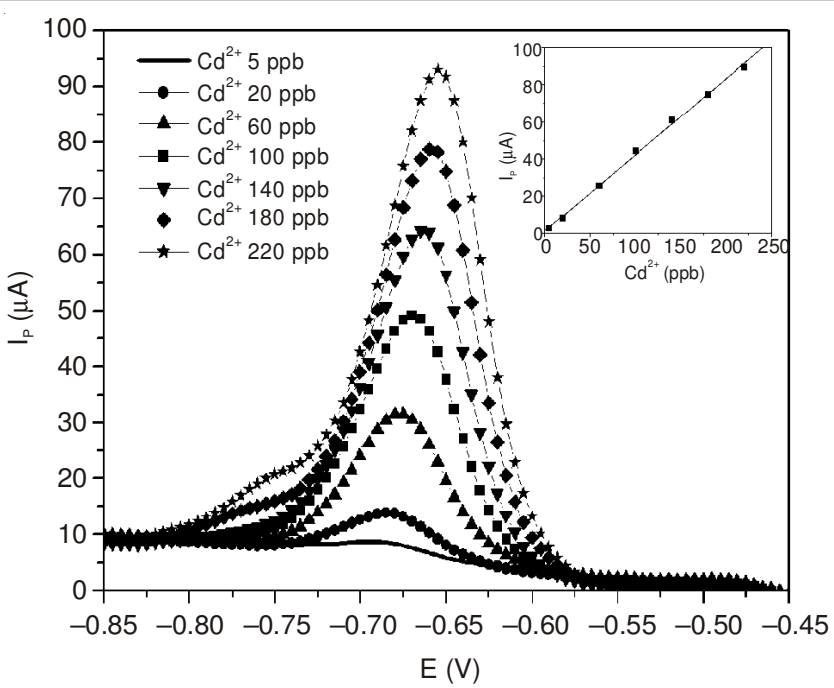

Fig. 6. ASDPVAs of different $\mathrm{Cd}^{2+}$ concentrations ranged from 5-220 $\mathrm{ppb}$ in 01.M phosphate buffer solution of $\mathrm{pH} 4$, built up on ILCNT-CPE; deposition potential: $-1 \mathrm{~V}$; deposition time: $240 \mathrm{~s}$. Background curve was substracted. The inset: calibration curve for determining $\mathrm{Cu}^{2+}$ in range of 5-220 ppb on IL-CNT-CPE

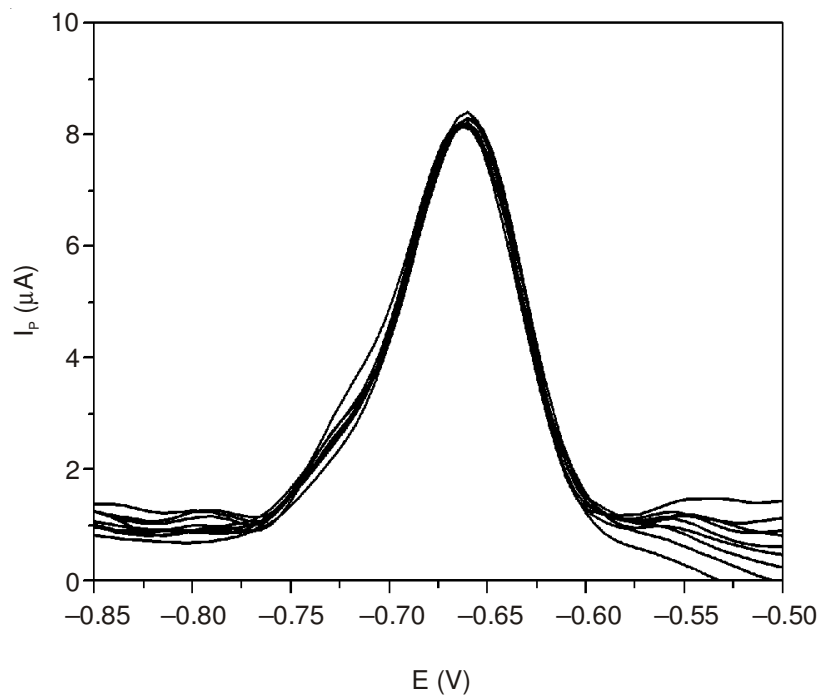

Fig. 7. ASDPVAs collected from ten separately measurements in $0.1 \mathrm{M}$ phosphate buffer solution containing $20 \mathrm{ppb} \mathrm{Cd}^{2+}$ at electrode modified with graphite powder/arbon nanotubes/paraffin oil/ $\mathrm{BmimBF}_{4}$ at 50 / 20/15/15 (\%) in weights, potential: $-1 \mathrm{~V}$; deposition time: $240 \mathrm{~s}$

in solution containing $20 \mathrm{ppb}$ of $\mathrm{Cd}^{2+}$, except $\mathrm{Cu}^{2+}$ and $\mathrm{Pb}^{2+}$ with 500 times higher was test. No interference in terms of anodic stripping current peaks was found. However, with the prerence of $\mathrm{Cu}^{2+}$ and $\mathrm{Pb}^{2+}$ only at 10 folds, peak of $\mathrm{Cd}^{2+}$ in study solution was depressed. Data is presented in Fig. 8.

The developed electrode was used to analyse a water sample collected from the Red river, a main river draining from the northern region of Vietnam, through Hanoi. Red river water sample was filtered through a Whatman GF/F glass fiber filter to remove suspended particulates and other materials and the $\mathrm{pH}$ was adjusted to 4 using phosphate buffer solution. Samples were analyzed within $48 \mathrm{~h}$.

Application of the voltammetric method using the modified electrodes described above did not show any traces of cadmium. Spiking the water sample with three standard additions of cadmium with different concentrations resulted 
TABLE-2

RATIOS OF SIGNAL OBTAINED BY $\mathrm{Cd}^{2+} /$ SIGNAL OBTAINED BY $\mathrm{Cd}^{2+}$ ADDED METALLIC IONS, \%

\begin{tabular}{|c|c|c|c|c|c|c|c|c|c|c|}
\hline $\begin{array}{c}\text { Concentration of } \mathrm{Cd}^{2+} / \\
\text { concentration of added ion }\end{array}$ & $\mathrm{Ca}^{2+}$ & $\mathrm{Ni}^{2+}$ & $\mathrm{Co}^{2+}$ & $\mathrm{Cr}^{3+}$ & $\mathrm{Fe}^{2+}$ & $\mathrm{Zn}^{2+}$ & $\mathrm{Al}^{3+}$ & $\mathrm{Mn}^{2+}$ & $\mathrm{Pb}^{2+}$ & $\mathrm{Cu}^{2+}$ \\
\hline $1: 1$ & 99.04 & 100.05 & 98.66 & 98.92 & 99.06 & 99.99 & 100.49 & 99.68 & 98.69 & 99.70 \\
\hline $1: 10$ & 100.06 & 98.47 & 99.18 & 100.82 & 98.80 & 98.91 & 99.91 & 98.36 & 94.45 & 66.24 \\
\hline $1: 20$ & 100.25 & 101.28 & 99.00 & 100.64 & 100.12 & 100.10 & 97.34 & 98.64 & 90.64 & 46.49 \\
\hline $1: 50$ & 98.60 & 100.80 & 100.27 & 100.64 & 99.78 & 99.32 & 95.79 & 99.23 & 86.86 & 36.22 \\
\hline $1: 100$ & 100.14 & 100.21 & 98.92 & 99.46 & 99.99 & 100.57 & 97.44 & 99.13 & $\mathrm{x}$ & $\mathrm{x}$ \\
\hline $1: 200$ & 99.76 & 100.54 & 96.29 & 96.45 & 96.20 & 100.55 & 97.01 & 98.95 & $\mathrm{x}$ & $\mathrm{x}$ \\
\hline $1: 1000$ & 94.74 & 79.95 & 99.06 & 73.11 & 97.66 & 71.57 & 93.90 & 97.06 & $\mathrm{x}$ & $\mathrm{x}$ \\
\hline
\end{tabular}

TABLE-3

RECOVERY OF $\mathrm{Cd}^{2+}$ FROM THE RED RIVER WATER SAMPLE

\begin{tabular}{|c|c|c|c|c|c|c|c|}
\hline No. & Original (ppb) & $\mathrm{Cd}^{2}$ & pp) & $\mathrm{Cd}^{2+}$ Found (ppb) & Average & Recovery (\%) & $\operatorname{RSD}(\%)$ \\
\hline \multirow{3}{*}{$\mathrm{S} 1$} & Not detected & & $1^{\mathrm{st}}$ & 20.38 & \multirow{3}{*}{18.98} & \multirow{3}{*}{94.9} & \multirow{3}{*}{6.4} \\
\hline & Not detected & 20 & $2^{\text {nd }}$ & 18.39 & & & \\
\hline & Not detected & & $3^{\text {rd }}$ & 18.17 & & & \\
\hline \multirow{3}{*}{$\mathrm{S} 2$} & Not detected & & $1^{\mathrm{st}}$ & 40.95 & \multirow{3}{*}{40.31} & \multirow{3}{*}{100.8} & \multirow{3}{*}{4.7} \\
\hline & Not detected & 40 & $2^{\text {nd }}$ & 41.79 & & & \\
\hline & Not detected & & $3^{\text {rd }}$ & 38.18 & & & \\
\hline \multirow{3}{*}{ S3 } & Not detected & & $1^{\mathrm{st}}$ & 84.04 & \multirow{3}{*}{80.00} & \multirow{3}{*}{100} & \multirow{3}{*}{4.4} \\
\hline & Not detected & 80 & $2^{\text {nd }}$ & 78.44 & & & \\
\hline & Not detected & & $3^{\text {rd }}$ & 77.53 & & & \\
\hline
\end{tabular}

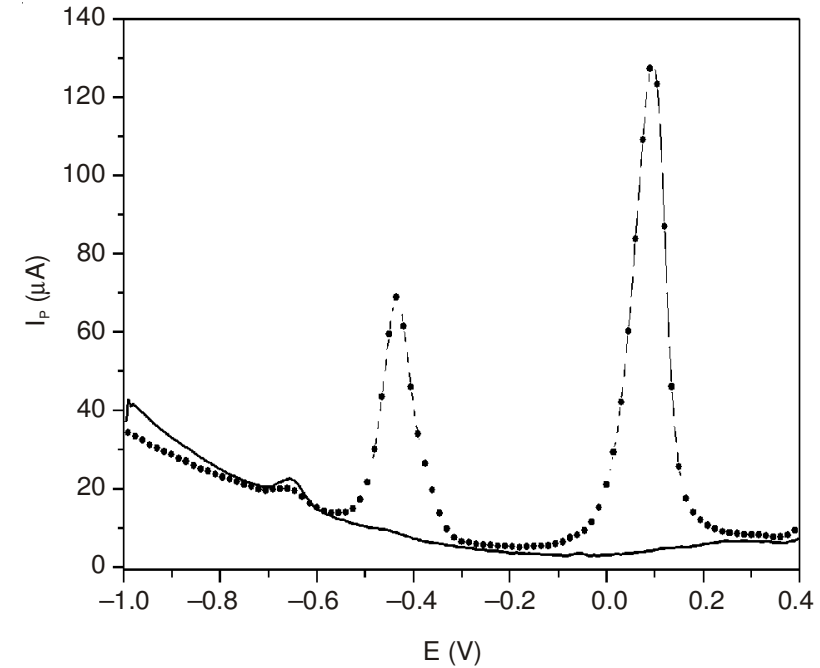

Fig. 8. ASDPVAs of $\mathrm{Cd}^{2+}$ at electrode modified with graphite powder/ carbon nanotubes/paraffin oil/BmimBF 4 at 50/20/15/15 (\%) in weights, deposition potential: $-1 \mathrm{~V}$; deposition time: 240 s. (1) $\mathrm{Cd}^{2+}$ $20 \mathrm{ppb}$ in $0.1 \mathrm{M}$ phosphate buffer solution (-); (2) $\mathrm{Cd}^{2+} 20 \mathrm{ppb}$ (peak at $-0.65 \mathrm{~V}$ ) added $\mathrm{Cu}^{2+}$ (peak at $+0.1 \mathrm{~V}$ ) and $\mathrm{Pb}^{2+}$ (peak at -0.4 V) $200 \mathrm{ppb}$ (-) in $0.1 \mathrm{M}$ phosphate buffer solution

in recoveries of 94-108\%, in comparison with the data of the calibration plots. Results are shown in Table-3.

\section{Conclusion}

We describe the preparation, optimization and practical application of the carbon paste electrode, IL-CPE and IL-CNTCPE prepared in situ at the carbon paste substrate electrode. The sensitivity of the carbon paste electrode was improved significantly by the incorporation of ionic liquid and IL-CNT and the detection limit for $\mathrm{Cd}^{2+}$ was archived at several ppb. The IL-CPE and IL-CNT-CPE exhibited strong stripping voltammetric signals for testing metal $\mathrm{Cd}^{2+}$ ion with a low background over the whole potential range of interest and revealed attractive electroanalytical performance in acidic medium of $\mathrm{pH} 4$. Finally, the practical applicability of the proposed electrode was successfully demonstrated with measurements of microgram per liter concentration levels of cadmium ions in natural water samples collected from the Red river in Hanoi, Vietnam. Combined with a lab constructed galvano-potentiosat, these portable and rapid electrochemical sensors, can be used effectively in on-site measurement with low cost and are extermely suitable for challenging environmental surveys in developing countries like Vietnam.

\section{ACKNOWLEDGEMENTS}

The present work was financially supported by Viet Nam's National Foundation for Science and Technology Development (NAFOSTED), code No. 104.03-2010.46, period 20102012. The authors thank Prof. Takashi Kakiuchi at Kyoto University for providing ionic liquids.

\section{REFERENCES}

1. T. Noyhouzer and D. Mandler, Anal. Chim. Acta, 684, 1 (2011).

2. J.F. van Staden and M.C. Matoetoe, Anal. Chim. Acta, 411, 201 (2000).

3. Y. Bonfil and E. Kirowa-Eisner, Anal. Chim. Acta, 457, 285 (2002).

4. J. Wang, Ü. Anik Kirgöz, J.-W. Mo, J. Lu, A. Nasser Kawde and A. Muck, Electrochem. Commun., 3, 203 (2001).

5. M. Chirea, V. García-Morales, J.A. Manzanares, C. Pereira, R. Gulaboski and F. Silva, J. Phys. Chem. B, 109, 21808 (2005).

6. R.M. Iost and F.N. Crespilho, Biosens. Bioelectron., 31, 1 (2012).

7. Y. Liu, X. Zou and S. Dong, Electrochem. Commun., 8, 1429 (2006).

8. L. Cao, Q. Li, J. Ji, P. Yan and T. Wang, Int. J. Electrochem. Soc., 8, 3074 (2013).

9. N. Muskal and D. Mandler, Electrochim. Acta, 45, 537 (1999).

10. S. Ben-Ali, D.A. Cook, P.N. Bartlett and A. Kuhn, J. Electroanal. Chem., 579, 181 (2005).

11. S.Y. Li, W.H. Ma, Y. Zhou, X.H. Chen, M.Y. Ma, Y.H. Xu, Z. Ding and X.H. Wu, Int. J. Electrochem. Sci., 8, 1802 (2013).

12. F. Ivanauskas, I. Kaunietis, V. Laurinavicius, J. Razumiene and R. Šimkus, J. Math. Chem., 43, 1516 (2008). 
13. L. Chu and X. Zhang, J. Nanosci. Nanotechnol., 12, 300 (2012).

14. Y.-C. Tsai, J.-M. Chen, S.-C. Li and F. Marken, Electrochem. Commun. 6, 917 (2004).

15. W. Sun, Z. Zhai, D. Wang, S. Liu and K. Jiao, Bioelectrochemistry, 74, 295 (2009).

16. R.G. Freitas, R.T.S. Oliveira, M.C. Santos, L.O.S. Bulhões and E.C. Pereira, Mater. Lett., 60, 1906 (2006).

17. D. Farina, K. Yoshida, T. Stieglitz and K.P. Koch, J. Appl. Physiol., 104, 821 (2008).

18. S. Schubert, M. Hermenau, J. Meiss, L. Müller-Meskamp and K. Leo, Adv. Funct. Mater., 22, 4993 (2012).

19. M. Bonne, K. Edler, J.G. Buchanan, D. Wolverson, E. Psillakis, M. Helton, W. Thielemans and F. Marken, J. Phys. Chem. C, 112, 2660 (2008).

20. S. Harrer, S. Ahmed, A. Afzali-Ardakani, B. Luan, P.S. Waggoner, X. Shao, H. Peng, D.L. Goldfarb, G.J. Martyna, S.M. Rossnagel, L. Deligianni and G.A. Stolovitzky, Langmuir, 26, 19191 (2010).

21. M. Musameh and J. Wang, Anal. Chim. Acta, 606, 45 (2008).

22. D.V. Chernyshov, N.V. Shvedene, E.R. Antipova and I.V. Pletnev, Anal. Chim. Acta, 621, 178 (2008).

23. D. Wei and A. Ivaska, Anal. Chim. Acta, 607, 126 (2008).

24. T. Torimoto, T. Tsuda, K. Okazaki and S. Kuwabata, Adv. Mater., 22, 1196 (2010).

25. M.J.A. Shiddiky and A.A.J. Torriero, Biosens. Bioelectron., 26, 1775 (2011).

26. M. Opallo and A. Lesniewski, J. Electroanal. Chem., 656, 2 (2011).

27. H. Liu, Y. Liu and J. Li, Phys. Chem. Chem. Phys., 12, 1685 (2010).

28. M.G. Freire, C.M. Neves, I.M. Marrucho, J.A. Coutinho and A.M. Fernandes, J. Phys. Chem. A, 114, 3744 (2010).

29. Y. Wang, J. Wu, T. Zhan, W. Sun and K. Jiao, Sensor Lett., 7, 1106 (2009).
30. Y. She, Y. Tang, H. Liu and P. He, Chem. Cent. J., 4, 17 (2010).

31. Y. Feng, Z.X. Liu, L.Y. Wang, H. Chen, Y.M. He and Q.H. Fan, Chin. Sci. Bull., 57, 4289 (2012).

32. A. Safavi, N. Maleki, S. Momeni and F. Tajabadi, Anal. Chim. Acta, 625, 8 (2008)

33. P. Zhang, S. Dong, G. Gu and T. Huang, Bull. Korean Chem. Soc., 31, 2949 (2010).

34. J. Ping, J. Wu, Y. Ying, M. Wang, G. Liu and M. Zhang, J. Agric. Food Chem., 59, 4418 (2011).

35. B.L. Li, Z.L. Wu, C.H. Xiong, H.Q. Luo and N.B. Li, Talanta, 88, 707 (2012).

36. S.B. Hocevar, I. Švancara, K. Vytras and B. Ogorevc, Electrochim. Acta, 51, 706 (2005).

37. T. Fukushima, A. Kosaka, Y. Yamamoto, T. Aimiya, S. Notazawa, T. Takigawa, T. Inabe and T. Aida, Small, 2, 554 (2006).

38. T. Fukushima, A. Kosaka, Y. Ishimura, T. Yamamoto, T. Takigawa, N. Ishii and T. Aida, Science, 300, 2072 (2003).

39. F. Zhao, X. Wu, M. Wang, Y. Liu, L. Gao and S. Dong, Anal. Chem., 76, 4960 (2004).

40. W. Tao, D. Pan, Q. Liu, S. Yao, Z. Nie and B. Han, Electroanalysis, 18, 1681 (2006)

41. F. Xiao, L. Liu, J. Li, J. Zeng and B. Zeng, Electroanalysis, 20, 2047 (2008).

42. F. Xiao, F. Zhao, J. Zeng and B. Zeng, Electrochem. Commun., 11, 1550 (2009).

43. B.G. Choi, H. Park, T.J. Park, D.H. Kim, S.Y. Lee and W.H. Hong, Electrochem. Commun., 11, 672 (2009).

44. X. Liu, Z. Ding, Y. He, Z. Xue, X. Zhao and X. Lu, Colloids Surf. B Biointerfaces, 79, 27 (2010).

45. J. Dong, Y. Hu, S. Zhu, J. Xu and Y. Xu, Anal. Bioanal. Chem., 396, 1755 (2010). 